Annals of Plant Sciences

ISSN: 2287-688X

OPEN ACCESS

Review Article

www.annalsofplantsciences.com

\title{
Plant Regeneration and Genetic Transformation in Buckwheat (Fagopyrum spp.), A Multipurpose Gluten Free Crop of High Nutraceutical Importance: A Critical Review
}

Mithilesh Kumar*, Ribha Saraswat

School of Life Sciences, Jaipur National University, Jagatpura, Jaipur- 302025 (Rajasthan), India.

Received: 05-12-2017; Accepted: 17-12-2017

\begin{abstract}
Buckwheat (Fagopyrum sp.) from family Polygonaceae, with its two main cultivated species (F. esculentumMoench. and F. tataricum) is mostly grown in hilly regions of Eurasia. It is a multipurpose gluten free crop having great nutraceutical value. For plant propagation several reports have been published and significant differences were noticed in culture protocols, genotypes and their success rates. A few studies report genetic transformation in buckwheat with varying degree of success. The present study reviews the in-vitro regeneration and genetic transformation reports in Fagopyrum spp. available in publically available literature and concludes on what needs to be done for the sustainable genetic improvement of buckwheat. A genotype independent high frequency in-vitro regeneration protocol compatible with high end stable genetic transformation is the need of the hour for sustained genetic improvement of this crop.
\end{abstract}

Keywords: Agrobacterium rhizogenes, A. tumefaciens, Buckwheat, Fagopyrum dibotrys, F. esculentum, F. tataricum, Genetic transformation, Hairy root culture, In-vitro regeneration, Organogenesis, Rutin, Somatic embryogenesis.

\section{Introduction}

Buckwheat belongs to genus Fagopyrum of family Polygonaceae and it includes 15 annual and perennial species mainly occurring in highlands of Euro-Asia (Arora and Engels, 1992; Ohnishi, 1995). Two main cultivated species are Fagopyrum esculentum (common buckwheat) and Fagopyrumtataricum (tartary buckwheat) (Chauhan et al., 2010). Although its name mentions 'wheat' in it, buckwheat is not taxonomically related to wheat and it has been accepted as a pseudo cereal crop (Joshi and Rana, 1995). The crop grows well in moist and cool climate with very little nutrient demand and is prevalently cultivated in northern hemisphere. As it can grow in rather poor soils and does not require extensive fertilization, its products are deemed to be a low-cost supplement to cereal grains. Interestingly, however, FAO states show a sharp decline in world area which harvested common buckwheat (from 4.9 MHa in 1992 to $2.01 \mathrm{MHa}$ in 2014). Hailed to be a multipurpose crop, buckwheat is used for both grains and greens such as food, feed, medicine and manure (Dutta et al., 2010). For human consumption, this crop is generally used as vegetable crop, honey crop and smother crop (Campbell, 1997), and however it has significant nutraceutical importance as well. The seeds of buckwheat are used to make bread, pancake, noodles and other food (Kim et al., 2010). Buckwheat is one of the most important gluten free crops and its seeds contain high amount (10-12.5\%) of protein (Greenway and Munns, 1980), large amount of lysine and a well-balanced content of other essential amino acids (Bratic et al., 2007). At present, the demand of buckwheat is due to its excellent properties- nutritional values based on the favorable composition of protein complexes with high content of lysine, fibrous material, mineral compounds, vitamins (thus making it quite complementary to cereal flours) and medicinal value due to presence of flavones, flavonoids, sterols, fagopyrin, and thiamin-binding proteins in buckwheat seeds and other parts thus possessing potential effects in treating

\section{${ }^{*}$ Corresponding Author:}

Dr. Mithilesh Kumar,

School of Life Sciences,

Jaipur National University, Jagatpura,

Jaipur- 302025 (Rajasthan), India.

E-mail: mithileshkumarbio@gmail.com some chronic diseases (Kreft et al., 2006). Out of all the bioflavonoids that buckwheat contains, the chief component $(80 \%)$ is rutin, which is a flavonol glycoside. The presence of rutin was reported in the processed groats, leaves, and flowers of buckwheat (Park et al., 2000). Rutin is a good dietary supplement and apart from having several medicinal properties like-vasconstrictive, spasmolitic, anti- inflammatory, anti-carcinogenic, antithrombotic, cytoprotective, it is also known to have very good anti-oxidant and anti-hypertensive properties. The seeds of tartary buckwheat contain higher amounts of rutin (about $0.8-1.7 \%$ d.w.) than those of common buckwheat (0.01\% d.w.) (Fabjan et al., 2003).

Despite all unique potential, buckwheat never achieved the status of important crop for cultivation and has never been widely adopted. Traditional breeding for improvement of this crop has been scarce. Fagopyrum spp. are diploid, $2 \mathrm{n}=16$; but tetraploid varieties either occur spontaneously or can be induced (Chauhan et al., 2010). Obstacles behind the limited conventional breeding are its strong self/cross-incompatibility, low seed set, indeterminate type of growth and flowering and its susceptibility to spring and fall frosts. The causes of low seed set are unknown but have been attributed to high temperature, plant water stress, plant age, incompatibility caused by heterostylism, defective reproductive organs, failure of fertilization and embryo and/or endosperm abortion (Slawinska et al., 2009). Poor germplasm collection, databases and scarce availability of wild relatives further limit the progress of varietal improvement. Vegetative propagation through cuttings or other conventional methods has not been successful in buckwheat. However, some efforts have been made to study in-vitro regeneration in Fagopyrum involving different types of approaches and starting material. Yamane was the first to demonstrate in-vitro regeneration in common buckwheat as early as 1974. Afterwards, during last four decades regeneration in buckwheat through tissue culture 
has attracted many researchers. Suvorova (2016) reviewed buckwheat tissue cultures and genetic transformation. The author opined that buckwheat regeneration evolved in many different ways and regenerants may be obtained from various explants utilizing different approaches and that tissue culture systems of buckwheat are available for use in both basic and applied research. We in the present work have however identified the gaps in the studies and endeavor to conclude on what needs to be done for improvement of tissue culture and transformation standardizations in this plant species. Buckwheat tissue culture system has very recently been utilized to gain understanding of the mechanisms that are responsible for the genetic stability of cells in the culture. Betekhtin et al., 2017 has reported such a study in tartary buckwheat. They analyzed the histological sections of morphogenic and non-morphogenic callus lines by transmission electron microscopy and described the morphology of the nuclei in these lines. The results showed that nonmorphogenic calli cells had aneuploidy, whereas greater genomic stability was identified in morphogenic callus lines.

Buckwheat is a salt-sensitive glycophyte and soil salinity significantly affects the growth and grain yields of its seeds (Chen et al., 2008). Thus, genetic improvement of buckwheat with higher salt tolerance and for other biotic and/or abiotic stresses would produce remarkable economic and medicinal benefits. Nothing very significant, however, has been done by buckwheat breeding in this context. For crop improvement, plant breeding has been a successful and time-tested approach to develop new varieties and hybrids. But by enlarge the approach can utilize the gene pool of the same plant species or its wild relatives to have any activity thereupon. The plant genetic engineering approach, in contrast, can pave the way to assess much wider gene pool across kingdoms and to incorporate agronomic and quality traits not present in any of the crop germplasm or its wild relatives. Although reports with high transformation efficiency is lacking, researchers find increasing interest in genetic transformation of buckwheat to incorporate some useful genes governing quality characters or to increase rutin content in buckwheat through hairy root culture. The present study reviews in-vitro regeneration reports and the methods, approaches, physical and nutritional requirements and success rates contained therein on Fagopyrum as well as reports on genetic transformation in Fagopyrum and the efficiency of the processes.

Plant Regeneration in Fagopyrum: Materials, Basal media and Media addenda and Incubation conditions

Plant Material: Plant tissue culture of Fagopyrum employs different parts of the plant body. Explants from either seedling or differentiated plant parts from mature plant body have been used. Yamane (1974), however, used mature seeds as explants, without any excision, whereas Neskovic et al., 1987 excised immature zygotic embryos and induced somatic embryogenesis in buckwheat. In all the previously published reports, the most widely used explants have been hypocotyl segments (Adachi, 1989; Lachmann and Adachi, 1990; Gumerova et al., 2001, 2003; Jin et al., 2000; Han et al., 2011; Kwon et al., 2013; Hou et al., 2014) and cotyledon pieces (Srejovik and Neskovic, 1981; Luthar and Marchetti, 1994; Woo et al., 2000; Lee et al., 2009) from axenically grown seedlings. Some reports have utilized both cotyledon and hypocotyl explants (Berbec et al., 1999; Klcova and Gubisova, 2008). The seedling explants, wherever have been used were not older than 14 days; mostly 5-7 days old germinated seedlings have been used for explants preparation. Explants from mature plants like leaf (Rajbhandari et al., 1995; Park et al., 1999; Woo et al., 2004), nodes (Chen et al., 2012; Majid et al., 2015) and petiole (Slawinska, 2009) have been used for plant regeneration in buckwheat. Anthers have been used for haploid production in buckwheat (Bohanec et al., 1993). Takahata in 1988 showed regeneration from inflorescence in $F$. esculentumand F. cymosum. Experimental materials used were either from diploid or tetraploid plants of buckwheat. Whereas immature zygotic embryos, cotyledon and hypocotyl explants were used for inducing somatic embryogenesis, explants from mature plant parts were employed for organogenesis mode of regeneration.

Sterilization of plant material: Explants isolation is preceded by surface sterilization. Various methods of sterilization were applied. In cases where seed or a seedling part have been used as explants, mostly seeds have been surface sterilized and surface sterilized seeds have been incubated for germination. Adachi et al., 1989, however, exposed dehulled seeds to chlorine gas and washed the seeds with sterile water before keeping the seeds for germination, whereas Berbec and Doroszewska (1999) surface sterilized the dehulled seeds with $10 \%$ aqueous solution of hydrogen superoxide and subjected for germination. Wherever the mature seeds have been subjected to surface sterilization, mostly the first step is washing with $70 \%$ ethanol, followed by treatment with sodium/calcium hypochlorite, or mercuric chloride or other disinfectants with varying concentration and time and then washing with sterile water to remove traces of disinfectants. (Gumerova et al., 2003; Lee et al., 2009; Han et al., 2011; Chen et al., 2012; Kwon et al., 2013). Disinfectors were usually supplemented with Tween surfactant. Seed were decapped and imbibed in autoclaved distilled water before placing for germination. Surface sterilized seeds or dehulled seeds after surface sterilization were germinated mostly on MS basal medium solidified with a gelling agent (Park et al., 1999; Jin et al., 2002; Klcova and Gubisova, 2008; Lee et al., 2009; Kwon et al., 2013; Hou et al., 2014). Some workers have, however, also utilized half strength MS basal salts along with varying concentrations of sucrose solidified with a gelling agent to germinate buckwheat seeds (Lachmann and Adachi, 1990; Berbec and Doroszewska, 1999; Kachonpadungkitti et al., 2001). On the other hand, Adachi et al., 1989 used simple agar plates to germinate the seeds and Woo et al., 2000 utilized sterile filter paper moistened with water to germinate the seeds.

Basal Media and Media Addenda: Experiments carried out on Fagopyrum for in-vitro regeneration mostly used Murashige and Skoog (1962) medium as basal medium and supplemented this medium with different plant growth regulators or other addenda. Other media formulations like Gamborg-B5 (1968), White (1954), RM1964 and Linsmaier and Skoog (1965) were also employed. Yamane, 1974 used White's basal medium and RM-1964 medium. Srejovik and Neskovic, 1981; Neskovic et al., 1987; Yui and Yoshida, 2001; and Gumerova et al., 2003, however, utilized Gamborg- B5 as basal medium. Berbec and Doroszewska, 1999 utilized Linsmaier and Skoog medium (1965) as basal medium. Different types of plant growth regulators were used as 
media addenda- Auxins 2, 4-D and NAA have been frequently used to induce either callus or regeneration and IAA and IBA have been used to induce roots. Whereas cytokinins BAP and Kinetin have been widely used for regeneration in Fagopyrum, TDZ and 2iP have also been used. Jin et al., 2002, however, utilized a more complex media by supplementing casein hydrolysate and yeast extract also in MS medium. Neskovic et al., 1987 also utilized $2 \mathrm{~g} / \mathrm{L}$ casein hydrolysate for pretreatment of explants for embryogenic callus induction.

Carbon Source: Sucrose has been mostly used as carbon source. Bohanec, 1993, however, showed that maltose can also be utilized as carbon source for Fagopyrum regeneration.

Gelling agents: Most of the reports utilized agar as gelling agent in various concentrations $(0.6-0.8 \%, \mathrm{w} / \mathrm{v})$. Klcova and Gubisova, 2008 screened three different types of gelling agent treatments- agar, Phytagel and agar along with Phytagel and came out with conclusion that $0.8 \%$ agar was the best suited gelling agent. Lee et al., 2009, however, have got good results with $0.3 \%$ Gelrite.

Culture conditions: In vitro cultures were usually maintained at temperature of $24 \pm 3^{\circ} \mathrm{C}$ and photoperiod of 16 hours under white fluorescent light in most of the reports. Berbec and Doroszewska (1999) have utilized a photoperiod of 12 hours to incubate the cultures at a temperature of $27^{\circ} \mathrm{C}$. Kachonpadungkitti et al., 2001, however, incubated the cultures at $27 \pm 2^{\circ} \mathrm{C}$ and under 8 hour's photoperiod. Park et al., 1999 used a lower temperature $\left(22^{\circ} \mathrm{C}\right)$ to incubate buckwheat in-vitro cultures.

A comparative and summarized view of explants used, regeneration modes, culture media, plant growth regulators and other media addenda and frequency of invitro regeneration in Fagopyrum esculentum Moench. is presented in Table 1.1 and that of other species of Fagopyrum is presented in Table 1.2.

Table 1.1: Explants, regeneration modes, media, plant growth regulators and other media addenda, and frequency of in-vitro regeneration in F. esculentum as reported in different studies

\begin{tabular}{|c|c|c|c|c|c|c|}
\hline Explant & Mode & Basal Media & Plant Growth Regulators & $\begin{array}{c}\text { Other } \\
\text { addenda }\end{array}$ & Frequency & Reference \\
\hline Immature zygotic embryo & $\begin{array}{c}\text { Somatic } \\
\text { embryogenesis }\end{array}$ & $\mathrm{B}_{5}$ Medium & $\begin{array}{l}\text { 2,4-D }(1-10 \mathrm{mg} / \mathrm{L}), \mathrm{KIN}(0.1 \mathrm{mg} / \mathrm{L}) \\
\mathrm{BAP}(2.2 \mathrm{mg} / \mathrm{L}), \mathrm{IAA}(0.17 \mathrm{mg} / \mathrm{L}), \mathrm{IBA} \\
(0.5 \mathrm{mg} / \mathrm{L})\end{array}$ & $\begin{array}{l}\text { Casein } \\
\text { hydrolysate }\end{array}$ & $37.1 \%$ & Neskovic et al., 1987 \\
\hline Leaf and Stem & $\begin{array}{l}\text { Somatic } \\
\text { embryogenesis }\end{array}$ & MS medium & 2,4-D (1 mg/L, $3 \mathrm{mg} / \mathrm{L})$ & -- & $1.6 \%-5.6 \%$ & Park et al., 1999 \\
\hline Cotyledon & $\begin{array}{l}\text { Somatic } \\
\text { embryogenesis }\end{array}$ & MS medium & $\begin{array}{l}\text { 2,4-D (1-3 mg/L), Kin }(0.2 \mathrm{mg} / \mathrm{L}), \text { BAP } \\
(0.5-5 \mathrm{mg} / \mathrm{L}), \mathrm{NAA}(0.1-0.5 \mathrm{mg} / \mathrm{L})\end{array}$ & -- & $32 \%$ & Woo et al., 2000 \\
\hline Hypocotyl & $\begin{array}{c}\text { Somatic } \\
\text { embryogenesis }\end{array}$ & B5 Medium & $\begin{array}{l}\text { 2,4-D }(2-15 \mathrm{mg} / \mathrm{L}), \mathrm{BA}(2.23 \mathrm{mg} / \mathrm{L}), \mathrm{IAA} \\
(0.175 \mathrm{mg} / \mathrm{L})\end{array}$ & -- & $95 \%$ & $\begin{array}{l}\text { Gumerova et al., } \\
2001,2003\end{array}$ \\
\hline Hypocotyl & $\begin{array}{c}\text { Somatic } \\
\text { embryogenesis }\end{array}$ & MS Medium & $\begin{array}{l}\text { 2,4-D }(1-8 \mathrm{mg} / \mathrm{L}), \mathrm{KIN}(1 \mathrm{mg} / \mathrm{L}), \mathrm{BAP} \\
(0.1-5 \mathrm{mg} / \mathrm{L}), \mathrm{IAA}(2 \mathrm{mg} / \mathrm{L})\end{array}$ & -- & $5 \%-20 \%$ & Kwon et al., 2013 \\
\hline Seed & Organogenesis & $\begin{array}{l}\text { White } \\
\text { medium, } \\
\text { RM-1964 } \\
\text { medium }\end{array}$ & $\begin{array}{c}\text { 2,4-D (1-10 mg/L), KIN }(0.2-1 \mathrm{mg} / \mathrm{L}) \\
\mathrm{IAA}(1-5 \mathrm{mg} / \mathrm{L})\end{array}$ & $\begin{array}{l}\text { Ascorbic acid, } \\
\text { casamino acid, } \\
\text { coconut milk, } \\
\text { yeast extract. }\end{array}$ & $73.3 \%$ & Yamane, 1974 \\
\hline Cotyledon & Organogenesis & B5 Medium & $\begin{array}{c}\text { 2,4-D }(1.0,5.0 \mathrm{mg} / \mathrm{L}), \mathrm{KIN}(0.1,1.0 \mathrm{mg} / \mathrm{L}) \\
\text { IAA }(1.75 \mathrm{mg} / \mathrm{L}), \mathrm{BAP}(22.5 \mathrm{mg} / \mathrm{L}) \\
\mathrm{IBA}(1.0 \mathrm{mg} / \mathrm{L})\end{array}$ & $\begin{array}{c}\text { Casein } \\
\text { hydrolysate }\end{array}$ & $40 \%$ & $\begin{array}{l}\text { Srejovic and } \\
\text { Neskovic, } 1981\end{array}$ \\
\hline Cotyledon & Organogenesis & $\begin{array}{l}\text { MS Medium+ } \\
\text { B }_{5} \text { Vits. }\end{array}$ & $\mathrm{IAA}(0.5 \mathrm{mg} / \mathrm{L}), \mathrm{IBA}(0.25 \mathrm{mg} / \mathrm{L})$ & -- & $4.37 \%$ & $\begin{array}{c}\text { Luther and } \\
\text { Marchetti, } 1994\end{array}$ \\
\hline Cotyledon and hypocotyl & Organogenesis & LS medium & $\begin{array}{l}\text { TDZ }(0.01-0.1 \mathrm{mg} / \mathrm{L}), \text { IAA }(0.5 \mathrm{mg} / \mathrm{L}), \\
\text { BAP }(0.5,0.7 \mathrm{mg} / \mathrm{L}), \text { ABA }(0.2 \mathrm{mg} / \mathrm{L}), 2,4- \\
\text { D }(3,5 \mathrm{mg} / \mathrm{l})\end{array}$ & -- & $30 \%-50 \%$ & $\begin{array}{l}\text { Berbec and } \\
\text { Doroszewska, } 1999\end{array}$ \\
\hline Hypocotyl & Organogenesis & MS Medium & $\begin{array}{l}\text { 2,4-D }(1-2 \mathrm{mg} / \mathrm{L}), \mathrm{BAP}(1-2 \mathrm{mg} / \mathrm{L}) \\
\mathrm{IBA}(0.2 \mathrm{mg} / \mathrm{L}), \mathrm{NAA}(0.2 \mathrm{mg} / \mathrm{L}, 0.4 \\
\mathrm{mg} / \mathrm{L}), \mathrm{KIN}(1 \mathrm{mg} / \mathrm{L}, 2 \mathrm{mg} / \mathrm{L})\end{array}$ & $\begin{array}{c}\text { Casein } \\
\text { hydrolysate }\end{array}$ & $80 \%$ & Jin et al., 2002 \\
\hline $\begin{array}{c}\text { Cotyledon (Co) \& } \\
\text { Hypocotyl } \\
\text { (Hy); Nodal segment } \\
\text { (No) and Shoot Apex (SA) }\end{array}$ & $\begin{array}{c}\text { Indirect } \\
\text { Organogenesis; } \\
\text { Direct } \\
\text { Organogenesis }\end{array}$ & $\begin{array}{l}\text { MS medium, } \\
\text { B5 Medium, } \\
\text { MS salts with } \\
\text { B5 vitamins }\end{array}$ & $\begin{array}{l}\mathrm{BA}(0.5-4.0 \mathrm{mg} / \mathrm{L}) \\
\operatorname{IAA}(0.2 \mathrm{mg} / \mathrm{L}) \\
\operatorname{IBA}(0.2-2.0 \mathrm{mg} / \mathrm{L})\end{array}$ & -- & $\begin{array}{l}\text { (Co) \& (Hy) : } 1.25- \\
2.44 \text { Shoots/explant } \\
\text { (No): } 4.1-4.8 \text { new } \\
\text { nodes/ explant } \\
\text { SA: } 2.65 \text { to } 3.33 \\
\text { nodes/ explant }\end{array}$ & $\begin{array}{c}\text { Klcova and } \\
\text { Gubisova, } 2008\end{array}$ \\
\hline Cotyledon & Organogenesis & MS medium & $\begin{array}{l}\mathrm{BAP}(0.5-6 \mathrm{mg} / \mathrm{L}), \mathrm{KIN}(0.5-6 \mathrm{mg} / \mathrm{L}) \\
\mathrm{TDZ}(0.5-6 \mathrm{mg} / \mathrm{L})\end{array}$ & $\mathrm{AgNO}_{3}$ & $72 \%$ & Lee, 2009 \\
\hline Hypocotyl & Organogenesis & MS medium & $\begin{array}{c}2,4-\mathrm{D}(1-4 \mathrm{mg} / \mathrm{L}), \mathrm{BAP}(0-2 \mathrm{mg} / \mathrm{L}) \\
\mathrm{NAA}(0.5-1.5 \mathrm{mg} / \mathrm{L})\end{array}$ & -- & $60 \%$ & Hou et al., 2015 \\
\hline Leaf & Organogenesis & MS medium & $\begin{array}{l}\mathrm{KIN}(0.2 \mathrm{mg} / \mathrm{L}, 0.5 \mathrm{mg} / \mathrm{L}), 2,4-\mathrm{D}(2 \\
\mathrm{mg} / \mathrm{L}), \mathrm{BAP}(2 \mathrm{mg} / / 1,3 \mathrm{mg} / \mathrm{L}), \mathrm{IAA} \\
\text { (various conc.), NAA }(0.2 \mathrm{mg} / \mathrm{L})\end{array}$ & -- & $30 \%$ & Woo et al., 2004 \\
\hline Leaf petiole & Organogenesis & $\begin{array}{l}\text { MS medium } \\
+\mathrm{B}_{5} \text { Vits. }\end{array}$ & $\mathrm{BA}, 2 \mathrm{iP}, \mathrm{TIBA}$ at $1 \mathrm{mg} / \mathrm{L}, 2 \mathrm{mg} / \mathrm{L}$ each) & -- & $98 \%$ & $\begin{array}{l}\text { Slawinska et al., } \\
2009\end{array}$ \\
\hline Nodal segment & Organogenesis & MS medium & $\begin{array}{l}\mathrm{IBA}(0.01-20 \mathrm{mg} / \mathrm{L}), \mathrm{NAA}(0.01-20 \\
\mathrm{mg} / \mathrm{L}), \mathrm{BAP}(0.01-20 \mathrm{mg} / \mathrm{L}), \mathrm{GA}(0.01- \\
10 \mathrm{mg} / \mathrm{L}), \mathrm{KIN}(0.01-20 \mathrm{mg} / \mathrm{L})\end{array}$ & -- & $\begin{array}{l}100 \% \\
10 \text { bloomed flowers } \\
\text { / explant }\end{array}$ & $\begin{array}{l}\text { Kachonpadungkitti } \\
\text { et al., } 2001\end{array}$ \\
\hline Immature Inflorescence & Organogenesis & $\begin{array}{l}\text { MS medium, } \\
\text { B5 Medium }\end{array}$ & $\begin{array}{l}\mathrm{NAA}(0-5 \mathrm{mg} / \mathrm{L}), \mathrm{BA}(0-2 \mathrm{mg} / \mathrm{L}), \mathrm{IBA} \\
(1 \mathrm{mg} / \mathrm{L}), 2,4-\mathrm{D}(0-5 \mathrm{mg} / \mathrm{L})\end{array}$ & -- & $40 \%-47.6 \%$ & Takahata, 1988 \\
\hline Anther & Organogenesis & B5 Medium & $\mathrm{NAA}(1-2 \mathrm{mg} / \mathrm{l}), \mathrm{BA}(0.5-2.5 \mathrm{mg} / \mathrm{l})$ & -- & $43.3 \%$ & $\begin{array}{l}\text { Yui and Yoshida, } \\
2001\end{array}$ \\
\hline Anther & $\begin{array}{l}\text { Haploid } \\
\text { Production }\end{array}$ & MS medium & $\begin{array}{l}\text { 2-iP (5 mg/L), 2,4-D (2 mg/L, } 4 \mathrm{mg} / \mathrm{L}) \\
\text { BAP(1 -2.5mg/L), IBA }(0.5 \mathrm{mg} / \mathrm{L}) \text {, IAA } \\
(0.1-1 \mathrm{mg} / \mathrm{L}), \text { KIN }(2 \mathrm{mg} / \mathrm{L})\end{array}$ & coconut milk & $1.36 \%$ & Bohanec et al., 1993 \\
\hline Hypocotyl Protoplast & Organogenesis & MS Medium & $\begin{array}{l}\text { 2,4-D }(0.1-1 \mathrm{mg} / \mathrm{L}), \mathrm{BAP}(0.1-2 \mathrm{mg} / \mathrm{L}) \\
\mathrm{NAA}(0.1 \mathrm{mg} / \mathrm{L}, 2 \mathrm{mg} / \mathrm{L}), \mathrm{GA}_{3}(0.1 \\
\mathrm{mg} / \mathrm{L})\end{array}$ & -- & Not mentioned & Adachi et al., 1989 \\
\hline
\end{tabular}


Table 1.2: Explants, regeneration modes, media, plant growth regulators and other media addenda, and frequency of $i n$ vitro regeneration in F. tataricum, F. dibotrys and F. cymosum as reported in different studies.

\begin{tabular}{|c|c|c|c|c|c|c|}
\hline Explant & Mode & $\begin{array}{c}\text { Basal } \\
\text { Media }\end{array}$ & Plant Growth Regulators & $\begin{array}{c}\text { Other } \\
\text { addenda }\end{array}$ & Frequency & Reference \\
\hline \multicolumn{7}{|c|}{ Fagopyrum tataricum } \\
\hline Hypocotyl & $\begin{array}{l}\text { Somatic } \\
\text { embryogenesis }\end{array}$ & $\begin{array}{l}\text { MS } \\
\text { Medium }\end{array}$ & $\begin{array}{l}\text { 2-iP }(10 \mathrm{mg} / \mathrm{L}), 2,4-\mathrm{D}(1-8 \mathrm{mg} / \mathrm{L}) \\
\text { BA }(0.1-2 \mathrm{mg} / \mathrm{L}), \mathrm{KIN}(0.2 \mathrm{mg} / \mathrm{L} \\
1 \mathrm{mg} / \mathrm{L}), \mathrm{TDZ}(0.5 \mathrm{mg} / \mathrm{L}, 2.0 \mathrm{mg} / \mathrm{L}) \\
\text { IAA }(0.1-1 \mathrm{mg} / \mathrm{L})\end{array}$ & -- & $\begin{array}{c}20 \%-90 \\
\%\end{array}$ & Han et al., 2011 \\
\hline $\begin{array}{l}\text { Cotyledon (Co) \& Hypocotyl } \\
\text { (Hy); }\end{array}$ & $\begin{array}{l}\text { Somatic } \\
\text { embryogenesis }\end{array}$ & MS medium & $\begin{array}{l}2,4-\mathrm{D}(2 \mathrm{mg} / \mathrm{L}), \mathrm{Kin}(1 \mathrm{mg} / \mathrm{L}) \\
\text { BA }(2 \mathrm{mg} / \mathrm{L}), \operatorname{IBA}(1 \mathrm{mg} / \mathrm{L})\end{array}$ & -- & $55.77 \%$ & $\begin{array}{l}\text { Wang et al., } \\
2016\end{array}$ \\
\hline Hypocotyl & Organogenesis & MS medium & $\begin{array}{l}2,4-\mathrm{D}(1-4 \mathrm{mg} / \mathrm{L}), \mathrm{NAA}(0.5-1.5 \\
\mathrm{mg} / \mathrm{L}), \mathrm{BA}(0.2-1.5 \mathrm{mg} / \mathrm{L})\end{array}$ & -- & $73 \%$ & Hou et al., 2015 \\
\hline \multicolumn{7}{|c|}{ Fagopyrum dibotrys } \\
\hline Nodal segment & Organogenesis & MS medium & $\begin{array}{l}\text { NAA }(0.2-1 \mathrm{mg} / \mathrm{L}), \mathrm{TDZ}(0.2 \mathrm{mg} / \mathrm{L} \text {, } \\
0.5 \mathrm{mg} / \mathrm{L}), \mathrm{IBA}(0.1-1 \mathrm{mg} / \mathrm{L}), \mathrm{IAA} \\
(0.1-1 \mathrm{mg} / \mathrm{L})\end{array}$ & -- & $90 \%$ & Chen et al., 2012 \\
\hline \multicolumn{7}{|c|}{ Fagopyrum cymosum } \\
\hline Immature Inflorescence & Organogenesis & $\mathrm{B}_{5}$ Medium & $\begin{array}{l}\mathrm{NAA}(0.2-5 \mathrm{mg} / \mathrm{L}), \mathrm{BA}(1 \mathrm{mg} / \mathrm{L}, 2 \\
\mathrm{mg} / \mathrm{L}), 2,4-\mathrm{D}(1-5 \mathrm{mg} / \mathrm{L}), \mathrm{IBA} \\
(1 \mathrm{mg} / \mathrm{L})\end{array}$ & -- & & $\begin{array}{l}\text { Takahata in } \\
1988\end{array}$ \\
\hline
\end{tabular}

Approaches in In-vitro regeneration of Fagopyrum via Somatic embryogenesis from Immature Zygotic Embryo:

Neskovicet al., 1987 found that 6\% sucrose is important for embryogenesis in Fagopyrum esculentum. Somatic embryos and buds from immature embryos were obtained maximally when immature zygotic embryos pretreated for 5 days with B5 salt solution, 2, 4-D $(5 \mathrm{mg} / \mathrm{L})+$ Kin. $(0.1 \mathrm{mg} / \mathrm{L})$ were incubated further on B5 medium supplemented with BAP $(2.2 \mathrm{mg} / \mathrm{L})+$ IAA $(0.17 \mathrm{mg} / \mathrm{L})$ They found that pretreatment with 2 , 4-D increased the number of explants which gave rise to embryogenic tissue, but the continued presence of 2, 4-D was not essential for a morphogenic response.

\section{From Cotyledon:}

Woo et al., 2000 reported somatic embryogenesis and plant regeneration from cotyledon tissues of Fagopyrum esculentum. Calli were induced with high frequency on MS medium supplemented with $2 \mathrm{mg} / \mathrm{L} 2,4-\mathrm{D}$ and $0.2 \mathrm{mg} / \mathrm{L}$ Kin. Embryogenesis with 32\% frequency was achieved on MS medium in the presence of BAP $(2.0 \mathrm{mg} / \mathrm{L})$ and Kin. $(0.2 \mathrm{mg} / \mathrm{L})$ with $3 \%$ sucrose. The somatic embryos were progressed and developed further on a maturation media, simply containing $1 / 2$ strength MS basal salts, vitamins and $3 \%$ sucrose.

\section{From Hypocotyls:}

An indirect somatic embryogenesis via the development of proembryogenic cell complexes (PECC) was observed in the in vitro cultured hypocotyl explants of 4-5-day-old buckwheat (Fagopyrum esculentum Moench.) seedlings by Gumerova et al., 2001, 2003. PECC development in this report on hypocotyls explants was shown to depend on culturing conditions, including 2, 4-D concentration and sucrose concentration, the period of explants exposure to 2, 4-D, and explants density. Hypocotyls of Tartary buckwheat were used as explants for regeneration via somatic embryogenesis by Han et al., 2011. Callus induction rates of $86.6 \%$ and $90 \%$ were achieved in 2, 4$\mathrm{D}(4.0 \mathrm{mg} / \mathrm{L})$ and $\mathrm{BA}(1.0 \mathrm{mg} / \mathrm{L})$ under dark, and 2 , 4-D $(2.5 \mathrm{mg} / \mathrm{L})$ and $\mathrm{BA}(1.5 \mathrm{mg} / \mathrm{L})$ under light conditions respectively. The globular and torpedo stage embryos progressed further and developed into plantlets with IAA
$(1.0 \mathrm{mg} / \mathrm{L})$, Kin. $(1.0 \mathrm{mg} / \mathrm{L})$, BA $(2.0 \mathrm{mg} / \mathrm{L})$ and TDZ (0.5mg/L). Kwon et al., 2013 cultured hypocoytl explants of Fagopyrum esculentum Moench on MS medium having 3\% sucrose with different combinations of auxins and cytokinins. A combination of BA (1.0mg/L) and 2, 4-D $(2.0 \mathrm{mg} / \mathrm{L})$ gave the maximal callus growth. Embryogenic calli were induced on MS media with $1 \mathrm{mg} / \mathrm{L} \mathrm{BA}$ and variable concentrations of 2, 4-D. interestingly, they showed that 2, $4 \mathrm{D}$ didn't have any significant effect on induction of embryogenic callus. From the embryogenic calli obtained, 5- $20 \%$ callus showed regeneration on MS medium containing IAA $(2.0 \mathrm{mg} / \mathrm{L})$, Kinetin $(1.0 \mathrm{mg} / \mathrm{L})$, BA $(1.0 \mathrm{mg} / \mathrm{L})$. Plantlet conversion was obtained with higher frequency when embryogenic calli with embryos and organized shoot primordial were transferred to MS basal medium with $3 \%$ sucrose.

Recently, Wang et al., 2016 reported somatic embryogenesis in two tartary buckwheat cultivars. The Yuanzi cultivar was better than Xichang in terms of morphogenic response and hypocotyls explants were found better than cotyledon explants for somatic embryogenesis based regeneration. Calli could be induced maximally $(98.96 \%)$ in a MS based medium supplemented with $2 \mathrm{mg} / \mathrm{L} 2$, 4-D and $1 \mathrm{mg} / \mathrm{L}$ Kin. MS medium fortified with $2 \mathrm{mg} / \mathrm{L} \mathrm{BA}$ and $1 \mathrm{mg} / \mathrm{L}$ Kin. Induced plant regeneration in $55.77 \%$ calli. Roots were induced in regenerated shoots on a half strength MS medium supplied with $1 \mathrm{mg} / \mathrm{L}$ IBA. $75 \%$ of the regenerated plantlets survived after transfer to soil. In this work, they also studied the morphogenic potential of cultures from these two cultivars for multiple shoot induction. In cv Yuanzi, $69.05 \%$ of regenerating propagules could be induced for multiple shoots on MS medium with $3 \mathrm{mg} / \mathrm{L}$ $\mathrm{BAP}$ and $1 \mathrm{mg} / \mathrm{L}$ TDZ.

\section{From Leaf and Stem:}

Park et al., 1999 reported 1.6 to 5.6\% rate of plant regeneration from callus derived from leaf and no regeneration from stem derived calli. Regeneration was obtained in hormone free medium. 


\section{Regeneration via Organogenesis} From Cotyledon and Hypocotyl:

Yamane in early 70's studied in-vitro differentiation in Shinano1 cultivar of buckwheat. Seeds were subjected to callus induction on modified White basal medium supplemented with varying concentrations $(1-10 \mathrm{mg} / \mathrm{L})$ of 2, 4-D, either alone or in combination with Kin. $(0.2,1$ $\mathrm{mg} / \mathrm{L})$. Similarly, varying concentrations of IAA (1, 5 $\mathrm{mg} / \mathrm{L})$ either alone or in combination with Kinetin $(0.2,1$ $\mathrm{mg} / \mathrm{L}$ ) were used. Calli developed from hypocotyls and cotyledon tissues from these seedlings optimally either in $10 \mathrm{mg} / \mathrm{L} \mathrm{2}$, 4-D or in a combination of $10 \mathrm{mg} / \mathrm{L} \mathrm{2,} \mathrm{4-D}$ and 0.2 or $1 \mathrm{mg} / \mathrm{L}$ Kinetin. Proliferated calli were then transferred to fresh RM-1964 medium modified with addition of $15 \%$ coconut milk and $3 \mathrm{~g} / \mathrm{l}$ yeast extract for development of shoots and roots. Srejovic and Neskovic, 1981 reported that regeneration of plants via organogenetic mode can be achieved in calli derived from cotyledon tissues. In their attempt to induce organogenesis, shoots were obtained with a modified B5 medium containing combination of 2 , $4-\mathrm{D}(1 \mathrm{mg} / \mathrm{L})$ and Kin. $(1 \mathrm{mg} / \mathrm{L})$, and rooting occurred when all hormones were omitted and B5 basal medium containing vitamins was used.

In-vitro regeneration protocol using hypocotyls of 5-day old seedlings of Fagopyrum esculentum was established by Jinet al., 2002. This study showed that calli could be induced on MS medium containing $1.0 \mathrm{mg} / \mathrm{L}$ to 2.0 $\mathrm{mg} / \mathrm{L} 2,4-\mathrm{D}$ and $1.5 \mathrm{mg} / \mathrm{L} \mathrm{BAP}$ and a high frequency (over $80 \%$ ) of shoot differentiation was obtained on MS medium supplemented with BAP $(2 \mathrm{mg} / \mathrm{L})$ and Kin. $(1 \mathrm{mg} / \mathrm{L})$. A combination of NAA $(0.2 \mathrm{mg} / \mathrm{L})$ and IBA $(0.2 \mathrm{mg} / \mathrm{L})$ promoted the formation of roots. They reported 2, 4-D and BAP as the main factors that influence callus induction. Hypocotyl explants of $F$. esculentum and F.tataricum were cultured by Houet al., 2015 on MS medium with varying concentrations of 2, 4-D (1$4 \mathrm{mg} / \mathrm{L})$ either alone or in combination with various levels of BA (0.5-1.5 mg/L) . A reasonably good frequency of regeneration with BA (1 mg/L) + NAA (1 $\mathrm{mg} / \mathrm{L})$ was observed in $F$. esculentum and with $\mathrm{BA}$ $(0.5 \mathrm{mg} / \mathrm{L})$ and NAA $(1 \mathrm{mg} / \mathrm{L})$ in F. tataricum.

Micropopagation of three buckwheat cultivars via indirect regeneration from cotyledon and hypocotyl, direct regeneration from nodal segments as well as cultivation of shoot apices was studied by Klcova and Gubisova in 2008. Whereas in case of indirect organogenesis with cotyledon and hypocotyls explants they reported no significant difference in regeneration frequencies over the media combinations tested, a sharp 2-3-fold increase in regeneration ability was noticed in the tested cultivars when nodal segments were subjected to $0.5-1.0 \mathrm{mg} / \mathrm{L} \mathrm{BA}$ supplemented MS medium. In case of shoot apices also, the study showed no significant difference among basal media combinations tested. The study, however, showed that rooting was improved up to $95.6 \%$ by adding $1 \mathrm{mg} / \mathrm{L}$ of IBA. Luthar and Marchetti, 1994 reported regeneration from mature cotyledon in Fagopyrum esculentum. Cotyledon and hypocotyl explants were used by Berbec and Doroszewska, 1999 to check the effect of TDZ on regeneration in three different cultivars of buckwheat. Among three, cultivar Kora showed best regeneration response when cultured on LS medium containing TDZ $(0.1 \mathrm{mg} / \mathrm{L})$ in combination with IAA $(0.05 \mathrm{mg} / \mathrm{L})$. In the work of Lee, 2009 with F. esculentumcotyledons, a concentration of $4 \mathrm{mg} / \mathrm{L}$ BAP showed optimal development of various stages of shoot organogenesis and additionally $7 \mathrm{mg} / \mathrm{L}$ of $\mathrm{AgNO}_{3}$ improved shoot regeneration frequency up to $30 \%$.

\section{From Leaf and Petiole:}

The induction of callus and subsequent differentiation and organogenesis were accomplished by Woo et al., 2004 in Fagopyrum esculentum from leaf explants. Kin. and 2, 4-D were found to be ideal for callusing. Kin. $(0.5 \mathrm{mg} / \mathrm{L})$ and BAP $(2.0 \mathrm{mg} / \mathrm{L})$ produced embryogenic and organized nodular regions. Organogenic callus showed high regeneration of plantlets with BAP $(2.0 \mathrm{mg} / \mathrm{L})$ and Kin. $(0.2 \mathrm{mg} / \mathrm{L})$ and in contrast, embryoids developed into plants in hormone free $1 / 2$ MS medium with $3 \%$ sucrose. However, with leaf petiole explants of Fagopyrum esculentum, most shoot regeneration was induced on MS medium containing Gamborg vitamins, BA, 2iP, 2, 3, 5 TIBA at $1 \mathrm{mg} / \mathrm{L}$ each and sucrose $30 \mathrm{~g} / \mathrm{L}$ by Slawinskaet al., 2009.

\section{From Node:}

Three cultivars of Fagopyrum esculentum were examined by Kachonpadungkittiet al., 2001 to induce in-vitro flowering. Nodal segments of 2 week- old seedlings were cultured in modified MS medium containing Kin. (0.021 mg/L) and $3 \%$ sucrose solidified with $0.8 \%$ agar. Various factors that affect flower induction were studied using nodal segments. Low concentration of Kinetin, short day $(8 \mathrm{~h}$ photoperiod), agar (1\%), Gellan gum $(0.1 \%)$, medium with aeration membrane, $\mathrm{NO}-3(30 \mathrm{mM})$ as only nitrogen source, sucrose concentration $(5 \%$ or $7 \%$ ) improved flower induction. One of the cultivar produced 100\% flower bud by $8^{\text {th }}$ week. Direct regeneration was reported by Chen et al., 2012. Adventitious buds were regenerated from stem nodal explants of Fagopyrum dibotrys in MS medium. $83 \%$ of explants developed axillary buds by BA $(1.0 \mathrm{mg} / \mathrm{L})$ and $86 \%$ of shoots progressed further for development with BA $(1 \mathrm{mg} / \mathrm{L})$ and NAA $(0.5 \mathrm{mg} / \mathrm{L})$. For rooting of the regenerated shoots, they noticed $1 / 2 \mathrm{MS}$ medium containing NAA $(0.5 \mathrm{mg} / \mathrm{L})$ was the best.

A regeneration protocol for Fagopyrum dibotrys through nodal explants was reported by Majid et al., 2015. Increase in BAP concentration up to $3 \mathrm{mg} / \mathrm{L}$ increased shoot propagation and further increase in concentration decreased the number of shoots. Optimal hormone for rooting was IBA $(2.5 \mathrm{mg} / \mathrm{L})$ and IAA $(2.0 \mathrm{mg} / \mathrm{L})$ in MS medium.

\section{From Inflorescence:}

Plant regeneration from immature inflorescence of common buckwheat was reported by Takahata in 1988 . Direct shoot production from the inflorescence of common buckwheat was promoted by the addition of NAA $(0.2 \mathrm{mg} / \mathrm{L})$ and $\mathrm{BA}(1 \mathrm{mg} / \mathrm{L})$ to $\mathrm{B} 5$ medium. MS medium with IBA $(1.0 \mathrm{mg} / \mathrm{L})$ was employed for rooting.

\section{From Anther:}

Haploid plant regeneration through cultured anthers of common buckwheat has been reported by Bohanecet al., 1993. They suggested that darkness preferably favors the regeneration on gellan-gum solidified media with $90 \mathrm{~g} / \mathrm{L}$ maltose, containing BA $(2.5 \mathrm{mg} / \mathrm{L})$ and IAA $(0.5 \mathrm{mg} / \mathrm{L})$. Anther culture was employed for plant regeneration of three Japanese cultivars by Yui and Yoshida, 2001. In two of the cultivars, the highest callus induction rate was attained on B5 basal medium with $2 \%$ sucrose supplemented with $1.0 \mathrm{mg} / \mathrm{L} \mathrm{NAA}$ and $2.0 \mathrm{mg} / \mathrm{L} \mathrm{BA}$, 
while a lower concentration of sucrose $(1 \%)$ and plant hormones $(0.5 \mathrm{mg} / \mathrm{I} \mathrm{NAA}$ and $1.0 \mathrm{mg} / \mathrm{L} \mathrm{BA})$ was good for the third cultivar. Cold pre-treatment of anthers promoted callus induction and some of the anther derived calli regenerated plantlets under callus inducing conditions in two of the cultivars. The regenerated plantlets were found to be diploid.

\section{From Protoplast:}

Adachi et al., 1989 reported regeneration of Fagopyrum esculentum plants from protoplasts isolated from hypocotyls in MS medium supplemented with gibberellic acid $(0.1 \mathrm{mg} / \mathrm{L})$. Continuous light with NAA $(0.1 \mathrm{mg} / \mathrm{L})$ and $\operatorname{BAP}(0.2 \mathrm{mg} / \mathrm{L})$ gave the best response in shoot formation. Lachmann and Adachi, 1990 reported callus regeneration from hypocotyl protoplasts of Fagopyrum tataricum Gaertn. on MS medium containing 6\% sucrose, $\mathrm{BA}(1.0 \mathrm{mg} / \mathrm{L})$ and NAA $(1.0 \mathrm{mg} / \mathrm{L})$.

\section{Genetic Transformation in Buckwheat}

Although none of the studies mentions that Fagopyrum is recalcitrant to transformation (like legumes) or to in-vitro regeneration (like cotton), very few attempts have been made to develop transgenic plants of buckwheat. Only successful attempt to transfer a useful gene was the transformation of buckwheat with $A t N H X 1$, a vacuolar $\mathrm{Na}(+) / \mathrm{H}(+)$ antiporter gene from Arabidopsis thaliana, which was said to yield higher rutin content in transgenic buckwheat plants, thus offering a possibility to tolerate salt stress in a better way. Rest of the reports are related to method development. Some have developed in-planta transformation methods to circumvent the need of in-vitro culture or aseptic techniques and relatively faster analysis of transformation efficiency and expression of transgene in plant cell milieu. No study reports genetic transformation in buckwheat by particle bombardment method or via any of the direct-DNA delivery methods. A summarized view of some genetic transformation parameters in Fagopyrum sp. is presented in Table 2. Three types of approaches for genetic transformation in buckwheat are evident from the available studies:

Table 2: Explants, bacterial strains and vectors, genes, analyzing techniques and frequency

\begin{tabular}{|c|c|c|c|c|c|c|}
\hline $\begin{array}{c}\begin{array}{c}\text { Transforming } \\
\text { Agent }\end{array} \\
\text { A. tumefaceins } \\
\begin{array}{c}\text { Involving tissue } \\
\text { culture }\end{array} \\
\end{array}$ & Explant & Strain : Vector & Gene & Detection Method & Frequency & References \\
\hline & Cotyledon & A281 : pGA472 & $n p t I I$ & $\begin{array}{l}\text { DNA hybridization } \\
\text { and NPTII enzyme } \\
\text { bioassays }\end{array}$ & $\begin{array}{l}\text { Not mentioned, } \\
\text { T1 segregated in 3:1 } \\
\text { ratio }\end{array}$ & Djukic et al,1992 \\
\hline & $\begin{array}{l}\text { Cotyledon, } \\
\text { hypocotyl }\end{array}$ & $\begin{array}{l}\text { LBA4404 : } \\
\text { pHZX1 }\end{array}$ & AtNHX1 & $\begin{array}{l}\text { PCR, Southern } \\
\text { blotting, Northern } \\
\text { blotting and RT- PCR }\end{array}$ & $\begin{array}{l}\text { Hypocotyls : } 24 \% \\
\text { Cotyledons: } 6 \%\end{array}$ & $\begin{array}{l}\text { Chen et al., 2007, } \\
2008\end{array}$ \\
\hline & Hypocotyl & $\begin{array}{l}\text { LBA4404: } \\
\text { pBI121 }\end{array}$ & $g u s A, n p t I I$ & PCR, GUS assay & $22-40 \%$ & Kim et al., 2001 \\
\hline \multicolumn{7}{|c|}{ In planta transformation } \\
\hline & $\begin{array}{l}\text { Apical } \\
\text { meristem }\end{array}$ & LBA4404 : pBI121 & $g u s A, n p t I I$ & $\begin{array}{l}\text { PCR, Southern } \\
\text { blotting }\end{array}$ & $70 \%$ & Kojima et al., 2000 \\
\hline & Plant & $\begin{array}{l}\text { EHA105: } \\
\text { pCAMBIA 2301, } \\
\text { pCAMBIA-PL }\end{array}$ & $g u s A, n p t I I$ & $\begin{array}{l}\text { GUS by Fluorescence } \\
\text { assay }\end{array}$ & $\begin{array}{l}\text { Vacuum infiltration } \\
\text { method has } 57.3 \text { fold } \\
\text { higher efficiency than } \\
\text { syringe infiltration }\end{array}$ & Bratic et al., 2007 \\
\hline & Seed & $\begin{array}{l}\text { GV3101: } \\
\text { pCAMBIA } 1301\end{array}$ & $\begin{array}{l}\text { gus } A, \text {, } p t I I \\
\text { gene }\end{array}$ & PCR & $22.72 \%$ & Chawla et al., 2012 \\
\hline \multicolumn{7}{|c|}{ Agrobacterium rhizogenes } \\
\hline \multirow[t]{2}{*}{$\begin{array}{l}\text { Involving tissue } \\
\text { culture }\end{array}$} & Stem & $15834:$ pBI121 & gus $A, n p t I I$ & $\begin{array}{l}\text { PCR analysis, } \\
\text { histochemical GUS } \\
\text { assay and Northern } \\
\text { hybridization }\end{array}$ & $90 \%$ & Kim et al., 2010 \\
\hline & $\begin{array}{l}\text { Seeding } \\
\text { explant }\end{array}$ & $\begin{array}{l}\text { R1000, R1200, } \\
\text { R13333, R15834, } \\
\text { R1601, LBA9402, } \\
\text { A4 }\end{array}$ & $\begin{array}{l}\operatorname{rol} / \mathrm{A}, \mathrm{B}, \mathrm{C} \\
\text { and D }\end{array}$ & PCR, HPLC & $65-100 \%$ & Thwe et al., 2016 \\
\hline
\end{tabular}

In-vitro Transformation and Regeneration:

The susceptibility of common buckwheat to Agrobacterium species was checked by Neskovic et al as early as 1990 . They found that tumors and hairy roots could be induced in F. esculentum Moench. by $A$. tumefaciens and A. rbizogenes, respectively. Out of several wild type strains of $A$. tumefaciens tested, strain A281 was found to be most virulent. Two years later, Djukic et al., 1992 (from the same group) became the first to report a successful genetic transformation in buckwheat (Fagopyrum esculentum Moench.). Their procedure involved co-cultivation of cotyledon explants for 2 days with A281 strain of Agrobacterium tumefaceins, harboring nptIIgene on pGA472 vector. DNA hybridization and NPTII enzyme bioassays were performed to validate transformants with resistance gene. Seeds from transgenic plants showed expected 3:1 segregation ratio when tested for kanamycin resistance in $\mathrm{T}_{1}$ generation. Kim et al., 2001 transformed hypocotyl explants of $F$. esculentum Moench. with $A$. tumefaciens LBA4404 harboring binary vector pBI121. A transformation frequency of $22-40 \%$ was achieved and transgenic plants were regenerated with a 4-8\% frequency. Putative transformants were analyzed by GUS staining and fluorometric assay and regenerated plants were confirmed by dectection-PCR for $n p t I I$ gene.

Agrobacterium-mediated method was used for transferring AtNHX1- tonoplast $\mathrm{Na}+/ \mathrm{H}+$ antiporter gene from Arabidopsis thaliana by Chen et al.2007, 2008 to regenerate salt-tolerant transgenic plants of Fagopyrum esculentum. 
They utilized cotyledon and hypocotyl explants as well as LBA4404 strain of Agrobacterium tumefacins to study the effects of expressing AtNHX/genein common buckwheat. Study reported many factors affecting transformation like - preculturing of explants, time period of bacterial infection and co-cultivation. A higher transformation frequency was achieved in hypocotyls when pre-cultured for 1-2 days. The infection of cotyledon explants were carried out for $20 \mathrm{~min}$. with bacterial culture and hypocotyl segments were infected for $25 \mathrm{~min}$. A co-cultivation period of 1-2 days was found appropriate with both the type of explants for getting higher transformation frequency. Role of acetosyringone was not found to be very important in this study. Transformants were screened and validated by techniques like PCR, Southern blotting, Northern blotting and RTPCR. The transgenic lines expressing $A t N H X 1$ gene were less affected by salt stress and had comparatively higher rutin content than the wild type and were shown to survive the salt stress regime as compared to control, non-transformed ones.

\section{In-planta Transformation:}

Kojima et al., 2000 exploited shoot apices of buckwheat to develop a meristem based in-planta transformation method by employing Agrobacterium tumefaceins (LBA4404, carrying pBI121). The procedure did not involve any invitro culture and newly established seedlings in soil pots with a pair of cotyledons were pricked with a needle to inoculate bacterial culture. The treated seedlings were cocultivated at $22^{\circ} \mathrm{C}$ for 3 days and later grown under 16 hours photoperiod in a growth chamber. Plants were raised to maturity, flowered and selfed. T1 seeds were germinated in presence of geneticin and transformation frequency of $70 \%$ was calculated by detection PCR as analytical test. When checked for expression, $36 \%$ of the T1 seedlings showed resistance to geneticin. Further, mutants from $T_{1}$ having abnormal insertions were confirmed by southern blotting.

In planta transformation of buckwheat was later reported by Bratic et al., 2007 by two different methods: vacuum infiltration and infiltration by syringe. Agrobacterium tumefaciens strain EHA105 with two vectors pCAMBIA2301 and PCAMBIA-PL was used. Outcomes of both methods were compared and it was stated that between the two methods vacuum infiltration is a preferable option for transformation in buckwheat as GUS activity was 57.3 folds higher than the value obtained in infiltration by syringe. A.tumefaciens culture density, vacuum conditions, and leaf maturity parameters were tested to make an effort on building up an easy transgenic plant development method in buckwheat. Chawla et al., 2012 studied in planta transformation in tartary buckwheat with Agrobacterium tumefaciens (strain GV3101 harboring pCAMBIA 1301). Imbibed seeds were co-cultivated for $60 \mathrm{~min}$. Integration of T-DNA was confirmed by histochemical GUS assay in leaf tissues of seedlings and PCR amplification of hptII gene. On an average, $22.72 \%$ transformation efficiency was noticed.

Transformation of Buckwheat for Enhanced Secondary Metabolite Production

Kim et al., 2010 experimented with stem explants of buckwheat for inducing hairy roots and thereby obtained higher rutin production in transformed hairy root clones. Agrobacterium rbizogenes strain 15834 with vector pBI121 was co-cultivated with explants for 2 days to transfer neomycin phosphotransferase (nptII) and gus $A$ genes. Results were confirmed by PCR analysis, staining for GUS activity and Northern hybridization. Rutin content was estimated by HPLC and it was shown that the amount of rutin content in hairy root clone was approximately 3 -fold higher than the normal, wild type roots.

Thwe et al., 2016 analyzed the transformation efficiencies of several Agrobacterium rbizogenes strains for induction of hairy roots in F. tataricum and investigated the expression levels of polypropanoid biosynthetic pathway genes in transformed hairy roots and also quantified the corresponding in-vitro synthesis of phenolic compounds and anthocyanins. For hairy roots in tartary buckwheat in this study, A. rbizogenes strain R1000 was found to be most efficient, as it showed highest transformation efficiency, highest growth rate, root number, root length and most importantly, highest anthocyanin and rutin content.

The effect of exogenous elicitors to enhance the flavonoids production was studied by Zhao et al., 2014 in hairy root cultures of tartary buckwheat. Yeast polysaccharide elicitor stimulated the functional metabolite production in hairy roots and a combination of elicitation with yeast polysaccharide and medium renewal process was found to yield 3.2-fold higher flavonoids production. Huang et al., 2016 was able to enhance the rutin and quercetin biosynthesis pathway genes in tartary buckwheat hairy root cultures by eliciting the hairy roots with UV-B radiation. They noticed a striking increase in rutin and quercetin production in UVB stressed hairy roots.

\section{Conclusion and Future Prospects}

All the previous outcomes from plant tissue culture of Fagopyrum species confirm that there were potential in reestablishing new plant body from various explants of its three species viz. F. esculentum, F. tataricum and F. dibotrys. Although significant number of studies report in-vitro regeneration of buckwheat with varying degree of success and utilizing germplasms from many different temperate geographical regions, the fact remains that a highfrequency, reproducible protocol is the need of the hour for its genetic improvement, supporting its propagation at relatively greater scale and for widening its adoption as a food crop. Reports published from different countries and utilization of specific germplasms or cultivars show that significant degree of genotype dependency exists for in-vitro regeneration in buckwheat. One possible approach to solve this may be to identify a germplasm having better regeneration abilities and to work out a high frequency regeneration method and that germplasm should be made available to all the labs working in the area, so that more and more researchers put their augmented effort in genetic transformation with useful genes for improvement of this less adapted and under-exploited crop and later introgress the traits in their local germplasms. Similarly, for genetic transformation in buckwheat a protocol standardizing all the factors that affect genetic transformation viz. Agrobacterium tumefaciens strain, culture density at which culture is to be harvested for transformation, vector choices, type of explants, cocultivation time period and temperature, requirement of Vir-inducing phenolic compounds is altogether missing. Also, strong and concerted efforts needed to improve this crop for tolerating several biotic and abiotic stress factors 
and thus more studies are required on the deployment of stress tolerance genes in buckwheat. Enhanced production of secondary metabolites or other nutraceuticals utilizing hairy root culture and cell culture in buckwheat is also going to be an area where researchers can pay more attention. The present review can be utilized by researchers, institutions and agribiotech companies to sustainably increase the propagation of this useful plant commercially. Genetic engineering led crop improvement of buckwheat will soon also attract agriculture institutions, food biotech companies as well as pharma concerns to tap better resource yields from this plant.

\section{Acknowledgement}

Authors are grateful to School of Life Sciences, Jaipur National University, Jaipur for providing necessary infrastructure and support for this work.

\section{References}

1. Adachi T, A Yamaguchi, Y Miike and E Hoffmann, Plant regeneration from protoplasts of common buckwheat (Fagopyrum esculentum), Plant Cell Reports, 8 (1989): 247-250.

2. Arora RK and JMM Engels, Buckwheat genetic resources in the himalayan region: Present status and future thrust, In Buckwheat Genetic Resources in East Asia, International Crop Network, 6 (1992): 87-91.

3. Berbec $\mathrm{A}$ and $\mathrm{T}$ Doroszewska, Regeneration in vitro of three cultivars of buckwheat (Fagopyrum esculentum Moench.) as affected by medium composition, Fagopyrum, 16 (1999): 49-52.

4. Betekhtin A, M Rojek, J Jaskowiak, A Milewska-Hendel, J Kwasniewska, Y Kostyukova, E Kurczynska, N Rumyantseva and R Hasterok, Nuclear genome stability in long-term cultivated callus lines of Fagopyrum tataricum (L.) Gaertn. PLOS ONE, 12.3 (2017): e0173537.

5. Bohanec B, M Neskovic and R Vujicic, Anther culture and androgenetic plant regeneration in buckwheat (Fagopyrum esculentum Moench), Plant Cell Tissue and Organ Culture, 35 (1993): 259-266.

6. Bratic A, DB Maji, JD Miljusjuki, ZS Jovanovi and V Maksimovi, In planta transformation of buckwheat (Fagopyrum esculentum Moench), Archives of Biological Sciences, 59 (2007): 135-138.

7. Campbell CG, Promoting the conservation and use of underutilized and neglected crops Buckwheat Fagopyrum esculentum Moench, 19 (1997): 27.

8. Chauhan RS, N Gupta, SK Sharma, JC Rana, TR Sharma and S Jana, Genetic and Genome Resources in Buckwheat - Present Status and Future Perspectives, European Journal of Plant Science and Biotechnology, 4.1 (2010): 33-44.

9. Chawla A, H Singh and A Kant, Development of In planta transformation method for Tartary Buckwheat (Fagopyrum tataricum), International Conference on Emerging Trends in Biotechnology, (2012): 45-46.

10. Chen LH, B Zhang and ZQ Xu, Genetic transformation of buckwheat (Fagopyrum esculentum Moench) with AtNHX1 gene and regeneration of salt-tolerant transgenic plants, Chinese Journal of Biotechnology, 23 (2007): 51-60.

11. Chen LH, B Zhang and ZQ Xu, Salt tolerance conferred by overexpression of Arabidopsis vacuolar $\mathrm{Na}(+) / \mathrm{H}(+)$ antiporter gene AtNHX1in common buckwheat (Fagopyrum esculentum), Transgenic Research, 17 (2008): 12132.

12. Chen $\mathrm{C}, \mathrm{J}$ Lan, $\mathrm{S}$ Xie, $\mathrm{S}$ Cui and $\mathrm{A} \mathrm{Li}$, In vitro propagation and quality evaluation of long-term micropropagated and conventionally grown Fagopyrum dibotrys Hara mutant, an important medicinal plant, Journal of Medicinal Plants Research, 6.15 (2012): 3003-3012.

13. Djukic J M, M Neskovic, $S$ Ninkovic and $R$ Crkvenjakov, Agrobacterium-mediated transformation and plant regeneration of buckwheat (Fagopyrum esculentum Moench.), Plant Cell Tissue and Organ Culture, 29 (1992): 101-108.

14. Dutta MNM, S Shah and P Kumar, Assessment of agromorphological, physiological and genetic diversity among buckwheat cultivars, Proceeding of the 11th International Symposium on Buckwheat, (2010): 94-101.

15. Fabjan N, J Rode, IJ Kosir, Z Wang, Z Zhang and I Kreft, Tartary buckwheat (Fagopyrum tataricum Gaertn.) as a source of dietary rutin and quercitin, Journalof Agriculture and Food Chemistry, 51 (2003): 6452-6455.

16. FAO

stats,

2017 , http://www.fao.org/faostat/en/\#compare

17. Gamborg OL, RA Miller and K Ojima, Nutrient requirements of suspension cultures of soybean root cells, Experimental Cell Research, 50 (1968): 151-158.

18. Greenway $\mathrm{H}$ and $\mathrm{R}$ Munns, Mechanisms of salt tolerance in nonhalophytes, Annual Review of Plant Physiology, 31 (1980): 149-190.

19. Gumerova EA, EI Gatina, SA Chuenkova and NI Rumyantseva, Somatic embryogenesis in common buckwheat Fagopyrum esculentum Moench, Proceeding of $8^{\text {th }}$ International Symposium on Buckwheat, (2001): 377-381.

20. Gumerova EA, EI Galeeva, SA Chuyenkova and NI Rumyantseva, Somatic embryogenesis and bud formation on cultured Fagopyrum esculentum hypocotyls, Russian Journal of Plant Physiology, 50.5 (2003): 640-645.

21. Han MH, AHM Kamal, YS Huh, AY Jeon, JS Bae, KY Chung, MS Lee, SU Park, HS Jeong and SH Woo, Regeneration of plantlet via somatic embryogenesis from hypocotyls of Tartary Buckwheat (Fagopyrum tataricum), Australian Journal of Crop Science, 5.7 (2011): 865-869.

22. Hou S, Z Sun, B Linghu, Y Wang, K Huang, D Xu and $\mathrm{Y}$ Han, Regeneration of buckwheat plantlets from hypocotyl and the influence of exogenous hormones on rutin content and rutin biosynthetic gene expression in vitro, Plant Cell Tissue and Organ Culture, 120.3 (2014): 1159-1167.

23. Huang X, J Yao, Y Zhao, D Xie, X Jiang and Z Xu, Efficient Rutin and Quercetin biosynthesis through Flavonoids-related gene expression in Fagopyrum tataricum Gaertn. Hairy Root Cultures with UV-B Irradiation, Frontiers in Plant Science, 7 (2016): 63. 
24. Jin $\mathrm{H}, \mathrm{J} \mathrm{Jia}$ and $\mathrm{J} \mathrm{Hao}$, Efficient plant regeneration in vitro in buckwheat, Plant Cell Tissue and Organ Culture 69 (2002): 293-295.

25. Joshi BD and RS Rana, Buckwheat (Fagopyrum esculentum), In Underutilized crops: Cereals and Pseudocereals, Ed. Williams, J.T. Chapman and Hall, London, (1995): 85127.

26. Kachonpadungkitti Y, S Romchatngoen, K Hasegawa and S Hisajima, Efficient flower induction from cultured buckwheat (Fagopyrum esculentumL.) node segments in vitro, Plant Growth Regulation, 35 (2001): 37-45.

27. Kim YK, H Xu, WT Park, NI Park, SY Lee and SU Park, Genetic transformation of buckwheat (Fagopyrum esculentum M.) with Agrobacterium rbizogenes and production of rutin in transformed root cultures, Australian Journal of Crop Science, 4.7 (2010): 485-490.

28. Klcova L and M Gubisova, Evaluation of different approaches to Buckwheat (Fagopyrum esculentumMoench.) micropropagation, Crech Journal of Genetics and Plant Breeding, 44.2 (2008): 66-72.

29. Kojima M, Y Arai, N Iwase, K Shirotori, H Shioiri and M Nozue, Development of a simple and efficient method for transformation of buckwheat plants (Fagopyrum esculentum) using Agrobacterium tumefaciens, Bioscience, Biotechnology and Biochemistry, 64 (2000): 845-847.

30. Kreft I, N Fabjan and K Yasumoto, Rutin content in buckwheat (Fagopyrum esculentum Moench) food materials and products, Food Chemistry, 98 (2006): 508-512.

31. Kwon SJ, MH Han, YS Huh, SK Roy, CW Lee and SH Woo, Plantlet regeneration via somatic embryogenesis from hypocotyls of common buckwheat (Fagopyrum esculentum Moench.), Korean Journal of Crop Science, 58.4 (2013): 331-335

32. Lachmann $\mathrm{S}$ and $\mathrm{T}$ Adachi, Callus regeneration from hypocotyl protoplasts of tartary buckwheat (Fagopyrum tatericum Gaertn.) Fagopyrum, 10 (1990): 62-64.

33. Lee SY, YK Kim, MD R Uddin, NI Park and SU Park, An efficient protocol for shoot organogenesis and plant regeneration of buckwheat (Fagopyrum esculentum), Romanian Biotechnological Letters, 14.4 (2009) : 4524-4529.

34. Linsmaier EM and F Skoog, Organic growth factor requirements of tobacco tissue culture, Plant Physiology, 21 (1965): 487-492.

35. Luthar $\mathrm{Z}$ and $\mathrm{S}$ Marchetti, Plant regeneration from mature cotyledons in buckwheat (Fagopyrum esculentum Moench) germplasm collection, Fagopyrum, 14 (1994): 65 -69 .

36. Majid A, ZA Kaloo, BM Padder and AH Munshi, An efficient in vitro regeneration protocol for an endandered medicinally important herb Fagopyrum dibotrys growing in Kashmir Himalaya, CIBTech Journal of Biotechnology, 4.1 (2015): 2319-3859.

37. Murashige T and F Skoog, A revised medium for rapid growth and bioassay of tobacco tissue culture. Physiologia Plantarum, 15 (1962): 473-497.

38. Neskovic M, R Vujicic and S Budimir, Somatic embryogenesis and bud formation from immature embryos of buckwheat (Fagopyrum esculentum Moench.), Plant Cell Reports, 6 (1987): 423-426.

39. Neskovic M, B Vinterhalter, J MiljusDjukic, S Ninkovic, D Vinterhalter, VJovanovic and J Knezevic, Susceptibility of buckwheat (Fagopyrum esculentum Moench.) to Agrobacterium tumefaciens and A. rbizogenes, Fagopyrum, 10 (1990): 57-61.

40. Ohnishi, Discovery of new Fagopyrum species and its implication for the studies of evolution of Fagopyrum and of the origin of cultivated buckwheat, Proceeding of the $6^{\text {th }}$ International Symposium on Buckwheat, (1995): 175-181.

41. Park CH, SL Lee, CS Chung, YB Shin, NS Kim, YB Kim, KM Yoon and YS Choi, Somatic embryogenesis and plant regeneration from leaf and stem explants of buckwheat, Fagopyrum, 16 (1999):53-56.

42. Park CH, YB Kim, YS Choi, K Heo, SL Kim, KC Lee, $\mathrm{KJ}$ Chang and HB Lee, Rutin content in food products processed from groats, leaves, and flowers of buckwheat, Fagopyrum, 17 (2000): 63-66.

43. Rajbhandari BP, S Dhaubhadel, DM Gautam, and BR Gautam, Plant regeneration via calli of leaf and stem explants in common buckwheat ecotypes, Current Advances in Buckwheat Research, (1995): 191-196.

44. Slawinska J, SK Kantartzi and RL Obendrof , In vitro organogenesis of Fagopyrum esculentum Moench (Ploygonaceae) as a method to study seed set in Buckwheat, European Journal of Plant Science and Biotechnology, 3 (2009): 75-78.

45. Srejovic V and M Neskovic, Regeneration of plants from cotyledon fragments of buckwheat (Fagopyrum esculentumMoench). Zeitschrift fur Pflanzenphysiologie, 104 (1981): 37-42.

46. Suvorova G, Buckwheat tissue cultures and genetic transformation, Molecular Breeding and Nutritional Aspects of Buckwheat, (2016): 365.

47. Takahata Y, Plant regeneration from cultured immature inflorescence of common buckwheat (Fagopyrum esculentum Moench) and perennial buckwheat (F. cymosum Meisn.), Japaneses Journal of Breeding, 38 (1988) 409-413.

48. Thwe A, MV Arasu, X Li, CH Park, SJ Kim, NA AlDhabi and SU Park, Effect of different Agrobacterium rbizogenes strains on hairy root induction and phenylpropanoid biosynthesis in tartary buckwheat (Fagopyrum tataricum Gaertn), Frontiers in Microbiology, 7 (2016): 318

49. Wang CL, XN Dong, MQ Ding, YX Tang, XM Zhu, YM Wu, ML Zhou and JR Shao, Plantlet regeneration of tartary buckwheat (Fagopyrum tataricum Gaertn.) in vitro tissue cultures, Protein and Peptide Letters, 23.5 ( 2016): 468-477.

50. White PR, The Cultivation of Animal and Plant Cells, Science, 1/e, Ronald Press, New York, (1954): 239.

51. Woo SH, A Nair, T Adachi and CG Campbell, Plant regeneration from cotyledon tissues of common buckwheat (Fagopyrum esculentum Moench), In Vitro Cellular and Developmental Biology- Plant, 36 (2000): 358361. 
52. Woo SH, M Takaoka, HS Kim, CH Park, T Adachi and SK Jong, Plant regeneration via shoot organogenesis from leaf callus culture of common buckwheat (Fagopyrum esculentum Moench.), Proceedings of the 9th Inernationall Symposium on Buckwheat, (2004 ): 61-65.

53. Yamane Y, Induced differentiation of buckwheat plants from subcultured calluses in vitro, Japanese Journal of Genetics, 49.3 (1974): 139-146.

54. Yui $\mathrm{M}$ and $\mathrm{T}$ Yoshida, Callus induction and plant regeneration in anther culture of Japanese buckwheat cultivars (Fagopyrum esculentum Moench), Fagopyrum, 18 (2001): 27-35.
55. Zhao JL, L Zou, CQ Zhang, YY Li, LX Peng, DB Xiang and $G$ Zhao, Efficient production of flavonoids in Fagopyrum tataricum hairy root cultures with yeast polysaccharide elicitation and medium renewal process, Pharmacognosy Magazine, 10.39 (2014): 234.

\section{Cite this article as:}

Mithilesh Kumar and Ribha Saraswat. Plant Regeneration and Genetic Transformation in Buckwheat (Fagopyrum spp.), A Multipurpose Gluten Free Crop of High Nutraceutical Importance: A Critical Review. Annals of Plant Sciences 7.1

(2018) pp. 1954-1963.

Source of support: School of Life Sciences, Jaipur National University, Jaipur, India.

Conflict of interest: Authors express no conflict of interest between them for the publication of this work. 